\title{
Chapter 2 \\ Generic Places, the Construction of Home and the Lived Experience of Cosmopolitanization
}

\author{
Jan Willem Duyvendak and Melissa Ley-Cervantes
}

\subsection{Introduction}

Where is your home?

My home is where I am. (Alejandro, Journalist)

In the soles of my feet. (Santiago, Journalist)

I carry my home on my back, like a snail. (Cristina, Physical therapist)

Home was my suitcase. (Sofía, Filmmaker)

The statements above seem to deeply resonate with the cosmopolitan ideal sparked by Diogenes who, as a Cynic philosopher, rejected tradition and local loyalties and found a sense of belonging to a much larger community - the kosmopolis and was the first person to have stated that he was a "citizen of the world" (Appiah 2007; Warf 2015). Born in the fifth century before the Christian era, Diogenes's cosmopolitanism has evolved through time and reached our days in the plural and complex form of cosmopolitanisms that in a broader sense refer to a sense of community and belonging across a multiplicity of identities and affiliations.

Cosmopolitanism becomes particularly pertinent in the context of the increased mobility of goods, people and ideas that characterizes modern life. In modern urban centers, people confront diversity on a daily basis and as such develop strategies to deal with difference and, ideally, embrace it (Warf 2015, 927). Nonetheless, there is chasm between the philosophical ideal of cosmopolitanism and the reality of people from a diverse array of backgrounds coexisting on a daily basis. Beck and Sznaider's notion of cosmopolitanization is useful in examining how this everyday

\footnotetext{
J. W. Duyvendak

University of Amsterdam, Amsterdam, The Netherlands

e-mail: w.g.j.duyvendak@uva.nl

M. Ley-Cervantes $(\bowtie)$

Independent Researcher, Mexico City, Mexico

e-mail: merluzaley@gmail.com 
engagement with difference might work since it de-romanticizes the ideas resulting from normative cosmopolitanisms by drawing attention to "the fact that the becoming cosmopolitan in reality is also, and even primarily, a function of coerced choices or a side-effect of unconscious decisions" $(2006,7)$.

Hence, as immediate access to different cultures increases through direct contact with people from diverse backgrounds but also more commonly and "banally" through the consumption of food, sartorial choices, music, etc., cosmopolitan orientations might increase (Beck 2008, 30). Yet this can also be accompanied by "a profound sense of a loss of territorial roots, of an erosion of the cultural distinctiveness of places" (Gupta and Ferguson 1992).

At the heart of the tension between immediate access to difference and a loss of distinctiveness of places is the proliferation of the so-called "generic places." This is often cited as a prime example of the homogenizing tendencies that come along with globalization. Knox explains that as cities lose their particularities and distinctiveness, their inhabitants tend to seek "authenticity" through everyday consumption in "commercially constructed spaces and places whose invented traditions, sanitized and simplified symbolism and commercialized heritage all make for convergence rather than spatial identity" $(2005,4)$. Some generic places constitute, in the words of Ulrich Beck, "interfaces between spaces of globality and spaces of territoriality" (Beck 2008, 33), providing continuity and certain cognitive assurances through a set of standardized practices and settings in the context of mobility and work as "a semantic and spatial Esperanto, allowing foreigners to feel at home no matter where they are" (Delalex 2002, 108). In this sense generic places are a product of globalization, but are they also a by-product of this (forced) cosmopolitanization.

This chapter contrasts the ideal (normative) version of cosmopolitanism versus the actual existing cosmopolitanisms and how actors might deal with the diversity and plurality in contemporary urban settings by analyzing the home-making experiences of young Mexican professionals living in Madrid who also experienced a great deal of spatial mobility. As the statements at the beginning of the chapter show, their feelings of home seem to be rightly placed within a cosmopolitan ideal in theory, but their everyday strategies to feel at home under conditions of movement, temporality and a closer relationship with cultural and socioeconomic difference reveal some contradictory feelings and strategies. In order to feel at home in the city, they need to ensconce themselves into generic places that provide not only continuity and familiarity but also the possibility of connecting (virtually and physically) with people that seem close to them, ultimately opting out from interacting with the perceived urban "other." Such generic places are important for cultivating feelings of home through specific processes of personalization enacted in urban environments by local and foreign middle and upper classes alike. These feelings are sustained by a communal belonging based not on a shared national identity but a class-based one.

The chapter is divided in five sections. The first section provides a brief overview of the way in which Madrid has been transformed in a very short period of time; section two untangles the relationship between place and home by analyzing the 
former along the public-private and particular-generic axes to understand the ways in which different places might foster feelings of home; section three deals with data and methods while section four constitutes the empirical discussion and follows the ways in which this group of people found home in generic places. Finally, section five provides some conclusions.

\subsection{Madrid: Building a Cosmopolitan Capital}

Once described by the New York Times travel section as "POOR Madrid. Stuck in the middle of Spain, the city has long been perceived as the provincial, sleepy sister to Barcelona," the capital city of Spain has been through a process of reformation and rebranding with the goal of positioning the city as a cosmopolitan interconnected capital (Wildman 2007).

This process was particularly visible between the incorporation of Spain into the European Union in 1994 and the start of the global financial crisis in 2008. The city started to attract multinational companies, got involved in an intensive infrastructure construction process and began to attract people from a myriad of places: Latin America, Northern Africa, Eastern Europe.

\footnotetext{
Madrid has changed utterly in a very short period of time. Since the nineteen eighties, a discourse in terms of competitive potential and globalisation has been clearly enunciated by politicians of every stripe who have succeeded one another in city and regional government. Their shared objective is to turn Madrid into an important element in the European system of cities. (Diaz-Orueta 2007, 186-7)
}

During the 1990s, several Spanish state-held companies - from banks to electricity, from oil to telecommunications - were privatized. Along with this process of privatization, Spain adopted the euro, a strong currency with a stable exchange rate that facilitated financial transactions at a global level. A great portion of these changes became territorialized in Madrid. By 2006, the city was hosting the corporate headquarters of seven out of the nine Spanish corporations included in Forbes's Global 500 list. In terms of infrastructure, the face of the city changed completely. Just to give some examples: the metro system went from having 120 kilometers of track in 1995 to 322 kilometers in 2006 (metromadrid.com), while the extension of Barajas airport in 2006 meant that $30 \%$ of the flights between Europe and Latin America land in Madrid (promomadrid.com). The demographic make-up of the city also changed radically; while in the late 1990 s, only $1 \%$ of the city's population was foreign, by 2007 foreigners constituted $16 \%$ of the population.

What the New York Times article was describing was a city that, like many others, was struggling between keeping the particularities and history of the local and an increasing interconnection to global capital, information, goods and people. Madrid's positioning as a global city involved the development of infrastructure oriented towards the tourist industry and middle-class consumption: chain restaurants, shopping malls, hotels and a sanitized display of "Spanishness." In doing so, 
many spaces in the city became generic and its original occupants were displaced (Díaz-Orueta 2007).

\subsection{Generic Places and the Construction of Home}

Following such narratives, it is no wonder that much of the inquiry on generic places has been focused on urban re-structuring processes that, more often than not, displace disadvantaged populations from the places they call home and create in lieu generic urban landscapes.

But in order to fully explore the potentialities of such generic places, we need to keep in mind that they constitute the backbone of globalization and cosmopolitanization by representing the infrastructure that sustains the enhanced mobility of goods, people and information (Beck 2008, 33). Moreover, since such places are the product of a process of standardization that facilitates communication and movement across physical and cultural borders, they feel immediately familiar. Such generic qualities provide certain "cognitive assurances" that have the potential of fostering home-feelings, independently of their exact location (Delalex 2002; Kesserling 2014; Nadler 2016).

Nonetheless, in order to really feel like "home," generic places have to become somewhat more personal. The potentiality of a generic place to foster feelings of home depends on the possibility of personalizing it, achieving some sense of control over space and imbuing it with meaning, that is to say, incorporating some elements that satisfy "personal" needs and preferences at a given point in time (see Duyvendak 2011; Ley-Cervantes and Duyvendak 2017). Since personalization of a space can function as a territorial marker that draws symbolic boundaries by displaying the identity of an individual or a group, such boundaries might have similar effects as an actual wall.

This does not mean that these places therefore become "particular": while they are still predominantly generic and recognizable as such for others, people give them a "personal touch" in order to make them feel like home. Particular places are almost by definition "personal," at least private ones. This is less true, though, for particular public spaces that can be rather un-homey for those who don't align with the public collective identity. Generic public places are also more difficult to "personalize" - a condition of feeling at home - than private generic places.

The following table develops a general classification of particular and generic places and the way in which personalization works. 


\begin{tabular}{l|l|l}
\hline & Particular & Generic \\
\hline Private & $\begin{array}{l}\text { Haven. Particular and private } \\
\text { Generally we understand home as particular } \\
\text { and private place. It is expected to reflect } \\
\text { someone's identity and in this sense the } \\
\text { personalization of such places is } \\
\text { encouraged. }\end{array}$ & $\begin{array}{l}\text { Harbor. Generic and private } \\
\text { Such places (hotels, coffee shops, etc.) } \\
\text { are made for people that either don't have } \\
\text { their own place to particularize and make } \\
\text { home or don't need a high level of } \\
\text { particularization to feel at home and in } \\
\text { contrast feel at home with little things. } \\
\text { Personalization of such places is allowed } \\
\text { to some degree. }\end{array}$ \\
\hline Public & $\begin{array}{l}\text { Heaven. Particular and public } \\
\text { Such places tend to reflect the identity of a } \\
\text { collectivity (nation, city, neighborhood). In } \\
\text { this sense, monuments, parks, museums and } \\
\text { buildings, etc., are designed to reflect a } \\
\text { certain history and collective identity, and } \\
\text { in so doing constitute part of a “collective } \\
\text { home." Individual personalization is } \\
\text { prohibited } \text { and, in some cases, penalized by } \\
\text { law; collective "personalization” may be } \\
\text { acceptable. }\end{array}$ & $\begin{array}{l}\text { Hub. Generic and public } \\
\text { that are supposed to be crossed or passed. } \\
\text { Motor highways, metro stations and some } \\
\text { public squares or streets come to mind. } \\
\text { Personalization of such places is often } \\
\text { discouraged, but temporary forms of } \\
\text { personalization can occur and are } \\
\text { exemplified by graffiti, flash mobs and } \\
\text { alternative modalities of use (waiting, } \\
\text { gathering, sleeping). }\end{array}$ \\
\hline
\end{tabular}

\subsection{Data and Methods}

Our data come from interviews with young Mexican professionals about their home-making strategies in Madrid. These interviews took place between 2008 and 2011. Thirty-four young Mexican professionals were interviewed (17 females, 17 males). At the time of the study, the youngest was twenty-four years old and the oldest forty-five years old; the interview subjects had arrived in Spain between 1995 and 2007. The time of stay in Spain varied between five months and sixteen years. All of them had at least a bachelor's degree or its equivalent, with thirty-one having undertaken or completed a postgraduate degree. The interviewees were a mix of postgraduate students, IT professionals, journalists, academics and CEOs.

While some of them were re-settlers, many of them were temporary movers. Some others could be called "chronic movers," people whose lives are marked by constant movement because of their lifestyles and career paths. What these young, middle-class migrants had in common was international mobility as a strategy of class reproduction in a world where traditional means of distinction, such as secondary and tertiary education, are blurring (Scott 2006; Bourdieu 1989).

As part of the methodological design, the informants were asked to choose a place in the city where they felt comfortable and at home. To our surprise, and this only highlights the proclivity to link home to generic places, many of the informants chose places like Starbucks and other chain restaurants. As the research progressed, more of the so-called generic places (airports, parks, coffee shops) emerged as 
significant places in home-making strategies while some other places, such as the neighborhoods where they lived or grew up, were identified as a source of alienation. This was particularly relevant for three scenarios: those who had recently arrived, those who were chronically mobile, and those who were recalling the earlier stages of re-settlement. All this begged the question: What is the role of generic places in the home-making strategies of this class of people?

\subsection{From the Ideal Cosmopolitan Subject to the Lived Experience of Cosmopolitanization}

These footloose Mexicans had incorporated constant mobility in their biographies mainly because of their profession. Such mobility soon became a lifestyle. Perhaps the person who best articulated this idea of the contemporary chronic mover was Amalia, a researcher whose professional life was constructed around a circuit of universities located in various cities in Spain, the UK and Mexico.

Do you feel at home here?

There is a beautiful book, the I Ching. Every time I look at it I get "The Walker" who is a person whose destiny is to be an outsider, he is always going from one place to another without a place to call home. I like it here because I find many walkers, people who share the feeling of not quite belonging to a place. (Amalia, Academic)

"The walker," as Amalia explained, can go from one place to another without a (particular) place to call home and through this mobility is able to find a home. This fits the ideal of the cosmopolitan subject whose sense of belonging to the world trumps other affiliations (national, religious, cultural, etc.) (Beck and Sznaider 2006, 6). But what happens at the ground level, in the everyday experiences of those inhabiting cosmopolitan places? As mentioned before, for this group of people generic private places such as coffee shops, hotel rooms and shopping malls have become important tools in their ability to feel at home under conditions of difference, temporality and movement. For this group of chronic movers and for some of the recently arrived, home was found in generic places because they provided connectivity, exclusivity and the possibility to move on.

\subsubsection{Place to Connect}

Research on corporate employees' personalizing habits in the work-place has shown that as a by-product of technological advances (cell phones, laptops) certain types of employees are now expected to work away from an established place of business (Duyvendak 2011, Tian and Belk 2005; Wells 2000). In this sense, the notion of home as a place for privacy, relaxation and intimacy begins to dissolve as remote technology allows the work sphere to intrude into the domestic sphere. In this 
setting, generic private places such as Starbucks capitalize on the constant blurring between domestic, leisure and work-related spheres and provide a place specifically designed to host some of the intersecting activities that once were performed in separated spheres.

As the boundaries of home and work are becoming constantly blurred for a great part of the professionalized labor force all over the world, the boundaries between home and away have also become blurred for the small universe of the chronically mobile. In this sense, the standardized practices of generic private places such as hotels and rental apartments, where functionality prevails over any other quality, provide a familiar setting where the landing for the chronically mobile is as seamless as possible. What is looked for in these places is a strong Wi-Fi connection and access to certain goods depending on personal preferences: books, newspapers, international cinema, a variety of restaurants.

\section{Where is your home?}

For the time being my home is here, but for me home is not a physical space, it is more within yourself. That's why I try to remain unattached, because if you become attached it is more difficult to move.

\section{What do you need to feel at home?}

Well, I need social relationships, freedom, a space with certain conditions: a nice WiFi connection, books, newspapers ... good food and people who love me. (Carlos, NGO worker)

Home then, becomes the place which may not be particular but where, often with the aid of technology, multiple spheres connect and become territorialized and personalized by the interests, needs and affections of the dweller. What becomes really important in the home-making strategies of highly mobile people (and the not so highly-mobile) is the ability to remain connected.

\subsubsection{A Place to Opt Out}

When I move around, to be honest, I am only interested on being surrounded by the pretty things ... I just don't want to deal with the ugly, I know I could adapt to that ("the ugly"). Do I want to? NO. (Amalia, Researcher)

When asked about the things they disliked about Madrid, the people who had recently arrived in Madrid would refer to very specific things about the city. That the streets were "dirty and smelled like pee," that there were "junkies sitting on my doorsteps," that "pedestrians are rude." When asked if that did not happen in their hometowns in Mexico, the answer they generally gave was either an emphatic "no," a more nuanced "maybe, but I never noticed" and, finally, for the ones who concurred that such things happened from where they came, that it was not something they confronted on a daily basis.

They did not notice because the urban middle classes in Mexico construct their everyday lives in safe havens, this is to say particular private places (gated communities, sheltered leisure spaces). Their interactions in generic public places are 
very limited and mediated through their access to private means of transportation. In a sense, difference in the public space is experienced through a car window.

Moving to Madrid changed things. The vast majority of the subjects of the study lived in central Madrid neighborhoods relatively close to their offices, businesses or universities. By walking or taking public transportation, they were confronted with difference not only in terms of national and ethnic background, but more importantly social class.

Their comfort zones were located in generic places such as chain restaurants or coffee shops in touristic areas of the city, which not only allowed them to opt out from interacting with "excluded others" but also from interacting under the terms set by the values, beliefs and practices of the city's long-term residents. Generic businesses share similar characteristics and standardized procedures that somewhat dilute the particularities of the places where they are located. In the words of Marc Augé (1995), "solitary contractuality" was perceived as familiar and comforting to the recently relocated since it offered standardized practices and facilitated the interaction inside the locale.

\subsubsection{A Place to Move}

It would be inaccurate to say that the places we have described are completely deterritorialized. It is rather that the ways in which these places are territorialized respond to a need to constantly move, hence a permanent personalization of a place hinders one's ability to feel at home while moving. The following example comes from a Mexican journalist who in 2007 became a target of Mexican organized crime and had to flee the country to work as a correspondent in Madrid:

Where is your home?

Among journalists there is a common phrase when you move: Are you going to unpack your bags? I already unpacked them. (But) If you look at my house you will surely think it is lacking, I don't hang up pictures or anything and I think in that sense I have become very functional. Sometimes I have to travel 16 times a month, and just think my home is where I am. (Alejandro, Journalist)

Whereas the immobile withdraw to feel at home, the mobile rich have more options. Crucially, the rich and mobile can financially secure their feeling at home; they also have the option to move on. This exit option is in itself a form of security that only a few privileged movers have. In this sense, Madrid was seen as a "neuralgic point" that connected Mexican professionals and worked as an ebb and flow for those people and places important to their personal biographies:

What do you like about the place where you live?

I think Madrid is like a neuralgic point for those who come to Europe or live within Europe. It is easy to get here, or out of here depending on the mood. This is one of the things I like the most. (Santiago, Journalist) 
While access to modern means of communication and travel have changed the way in which privileged movers relate to places and people, this does not mean that their homes are completely detached from particular places. Rather, their attachments are no longer "given" but purposefully constructed and maintained. In the words of Savage et al. (2005): "Belonging is not that of an individual to a fixed community rooted in place, but rather, one in which the place becomes valuable to the individual" (80) while "elective belonging involves choosing a place to live amongst your own kind, with the result that having local friends becomes an endorsement of one's place of residence" (85). Because of their access to certain goods and means of communication, privileged movers can opt out from places that might not provide comfort or a homey feeling; they can also simply move elsewhere.

\subsection{Conclusion}

This chapter has shown the chasm between the idea(l) of cosmopolitanism and the actual practicalities of everyday life in the face of the cosmopolitanization of places and individual biographies, particularly when it comes to the resources to feel at home under such conditions. Although some migrants might be able to build homes in particular and private places, such homes involve a financial and, more importantly, time investment that many immigrants cannot or will not afford. Although more privileged migrants have resources to create and sustain private and particular places (individual homes or gated communities), sometimes the ways in which they particularize their homes and display their identity are not in tune with the dominant majority.

However, as we have shown, (some) privileged movers are able to "control" and therefore feel at home in generic places, particularly private ones (such as shopping malls, hotels) while avoiding un-homey generic public places that are difficult to "personalize" (except when they successfully "privatize" these public spaces, e.g., by going to private lounges at airports).

Thus, generic places are not all inherently un-homey. While their homogeneity and standardization might be the central reason to define them as void of meaning and as a threat to particular home-places, such standardization can provide familiarity and cognitive assurances for international movers and for many who move inside the city as well. The problem seems to be that while generic private places allow certain degrees of personalization and thus have the potential to engender feelings of home, generic public places, especially those for the resource poor, are becoming increasingly hostile towards any attempts at personalization. Without particular and private places or access to generic private places, many people are left without options to find ways to feel at home.

While the most mobile and the most immobile differ on the importance they attach to particular places, what makes them feel at home is the same. For both, familiarity is a necessary, though not a sufficient, condition to feel at home. In the case of the privileged and highly mobile, familiarity is guaranteed in the generic 
places described here. However, there is more to these places than just familiarity. These "footloose" spots are also standardized, secure, and often segregated. In this sense, the differences between the more and less mobile often run parallel with class; their divergent ways of feeling at home often have class-specific consequences. First, the spread of the generic places of the rich and mobile may threaten the poor, who may be displaced to create space for "generic development." Second, it is not only generic goods for the rich and mobile (like hotel chains) that are spreading around the world. Starbucks and McDonald's do so as well, catering to many less mobile inhabitants and, in the Spanish case, replacing the traditional (and often subsidized) businesses de toda la vida. Third, clashes between the more and less mobile are not always clashes between rich and poor. Next to inter-class relations, intra-class relations become tense as well. In cities and neighborhoods in their countries of arrival, migrants can unintentionally upset the jealously guarded places of the native population. Lastly, mobility in the form of migration of the poor tends to disproportionately affect disadvantaged groups in countries of arrival for, as we have shown, more privileged movers always have an exit strategy from unfavorable conditions.

\section{References}

Appiah, K. A. (2007). Global citizenship. 75 Fordham Law Review. Available at: https://ir.lawnet. fordham.edu/flr/vol75/iss5/3.

Augé, M. (1995). Non-places, introduction to an anthropology of supermodernity. London: Verso.

Beck, U. (2008). Mobility and the cosmopolitan perspective. In W. Canzler, V. Kaufmann \& S. Kesselring (Eds.), Tracing mobilities: Towards a cosmopolitan perspective (pp. 25-36). Burlington: Ashgate.

Beck, U., \& Sznaider, N. (2006). Unpacking cosmopolitanism for the social sciences: A research agenda. British Journal of Sociology, 57(1), 1-23.

Bourdieu, P. (1989). Social space and symbolic power. Sociological Theory, 7(1), 14-25.

Delalex, G. (2002). Non-places: The everyday experience of flows. disClosure: A Journal of Social Theory, 11(9), 101-115.

Diaz-Orueta, F. (2007). Madrid: Urban regeneration projects and social mobilization. Cities, 24(3), 183-193.

Duyvendak, J. W. (2011). The politics of home: Belonging and Nostalgia in Western Europe and the United States. London: Palgrave Macmillan.

Gupta, A., \& Ferguson, J. (1992). Beyond 'culture': Space, identity, and the politics of difference. Cultural Anthropology, 7(1), 6-23.

Kesserling, S. 2014. Mobility, power and the emerging new mobilities regimes. Sociologica, 1(January-April).

Knox, P. (2005). Creating ordinary places: Slow cities in a fast world. Journal of Urban Design, 10(1), 1-11.

Ley-Cervantes, M. (2012). Stuck in the Middle: Home-making strategies of Mexican Middling Migrants. Ph.D. Thesis, Autonomous University of Madrid.

Ley-Cervantes, M., \& Duyvendak, J. W. (2017). At home in generic places: Personalizing strategies of the mobile rich. Journal of Housing and the Built Environment, 32(1), 63-76. 
Nadler, R. (2016). Plug\&Play places: Subjective standardization of places in multilocal lifeworlds. In P. Pucci \& M. Colleoni (Eds.), Understanding mobilities for designing contemporary cities (pp. 109-128). Heidelberg: Springer.

Noya, J. (2004). La imagen de América Latina en España. Real Instituto El Cano, documento de 370 trabajo, 40. Retrieved 11 February at http://biblioteca.ribei.org/684/

Savage, M., Bagnall, G., \& Longhurst, B. (2005). Globalization and belonging. London: Sage.

Scott, S. (2006). The social morphology of skilled migration: The case of the British middle class in Paris. Journal of Ethnic and Migration Studies, 32(7), 1105-1129.

Tian, K., \& Belk, R. (2005). Extended self and possessions in the workplace. Journal of Consumer Research, 32(2), 297-310.

Warf, B. (2015). Global cities, cosmopolitanism, and geographies of tolerance. Urban Geography, 36(6), 927-946.

Wells, M. (2000). Office clutter of meaningful personal displays: The role of office personalization in employee and organizational well being. Journal of Environmental Psychology, 20(3), 239-255.

Wildman, S. (2007, 28 January). 36 hours in Madrid. New York Times.

Open Access This chapter is licensed under the terms of the Creative Commons Attribution 4.0 International License (http://creativecommons.org/licenses/by/4.0/), which permits use, sharing, adaptation, distribution and reproduction in any medium or format, as long as you give appropriate credit to the original author(s) and the source, provide a link to the Creative Commons license and indicate if changes were made.

The images or other third party material in this chapter are included in the chapter's Creative Commons license, unless indicated otherwise in a credit line to the material. If material is not included in the chapter's Creative Commons license and your intended use is not permitted by statutory regulation or exceeds the permitted use, you will need to obtain permission directly from the copyright holder. 